Article

\title{
Members of the Polish Language Council on the Problems of Linguistic Diversity and Linguistic Inclusion in Poland
}

\author{
Tadeusz Wallas and Bartosz Hordecki* \\ Faculty of Political Science and Journalism, Adam Mickiewicz University, 61-614 Poznań, Poland; \\ E-Mails: tadeusz.wallas@amu.edu.pl (T.W.), bartosz.hordecki@amu.edu.pl (B.H.) \\ * Corresponding author
}

Submitted: 20 August 2020 | Accepted: 26 October 2020 | Published: 14 January 2021

\begin{abstract}
The last couple of decades have brought a significant increase in personal movement from and to Poland. In consequence, it is very probable that the issues of linguistic diversity and linguistic inclusion more and more frequently will become subjects of multi-level and multi-institutional discussion reshaping the Polish public sphere. It is a matter of consideration which institutions will take leading positions in this debate, formulating main narratives and polemics. However, answering its advisory and opinion-making responsibilities, the Polish Language Council may be expected as one among the crucial actors in this discourse. The article presents pivotal attitudes of the Council's members referring to the problem of linguistic diversity and linguistic inclusion in Poland. The presentation of the sources is combined with endeavours to answer the question: Do these materials allow considering the Council as a strong candidate for an essential designer of incoming public debate on linguistic diversity and linguistic inclusion in Poland? The research is conducted concerning the main assumptions of Joshua Fishman's (1997) sociology of language and Harold Schiffman's (2006) analysis of language policies as parts of linguistic cultures. Moreover, the methodological foundation of the text is supported by a general theoretical framework of historical institutionalism, and finally by Peter M. Haas's conceptualisation of 'epistemic community.'
\end{abstract}

\section{Keywords}

linguistic diversity; linguistic inclusion; migrations in Central Europe; multilingualism; Polish language; Polish Language Council

Issue

This article is part of the issue "Social Inclusion and Multilingualism: The Impact of Linguistic Justice, Economy of Language and Language Policy" edited by László Marácz (University of Amsterdam, The Netherlands / L. N. Gumilyov Eurasian National University, Kazakhstan) and Zsombor Csata (Babeș-Bolyai University, Romania / Hungarian Academy of Sciences, Hungary).

(C) 2021 by the authors; licensee Cogitatio (Lisbon, Portugal). This article is licensed under a Creative Commons Attribution 4.0 International License (CC BY).

\section{Introduction}

Public debates on linguistic diversity and linguistic inclusion in the context of migration flows are a frequent subject of research. Analysis and interpretation of such debates are also within the spectrum of interests of numerous disciplines and sub-disciplines coconstituting the sphere of contemporary humanities and social science.

One of them, although less popular than sociolinguistics, is the sociology of language in a sense proposed by Joshua Fishman. Studies in this area allow focusing on interactions between the use of language and its social conditions. In consequence, "the sociology of language focuses upon the entire gamut of topics related to the social organisation of language behaviour, including not only language usage per se, but also language attitudes and overt behaviours toward language and language users" (Fishman, 1997, p. 25).

Among various dimensions remaining within the interest of broadly understood sociology of language, political aspects of linguistic phenomena should also be located. Here belong studies on the opinions of key socio-political actors who co-shape or may have the 
potential to co-shape collective perceptions and practices regarding the organisation and implementation of language policies.

The article approaches selected views delivered by members of an institution obliged by law to participate in the process of conceptualising Polish language policy, i.e., the Polish Language Council. Their opinions are related to linguistic diversity and linguistic inclusion in the conditions of increased migration from and to Poland. These movements stimulate the public debate on directions of the state's activity in the mentioned area. Moreover, along with the intensification of migration flows, the linguistic situation in the territory of Poland significantly diversifies, providing both new possibilities and challenges.

The attitudes of the Council's members are perceived as vital elements of the Polish linguistic culture, understood as a specific example of linguistic culture in general, defined by Harold Schiffman "as the totality of ideas, values, beliefs, attitudes, prejudices, myths, religious structures, and all the other cultural baggage that speakers bring to their dealings with language" (Schiffman, 2006, p. 112; emphasis in original).

Simultaneously, it is not forgotten that the analysed sources were delivered by the representatives of an institution belonging to the system of state agendas. It was assumed in the spirit of historic-institutional studies that these do not develop themselves unconditionally but are subjected to the influence of longue durée. Thus, to interpret their statements, it is generally necessary to present two dimensions co-constituting context of their appearance. The first dimension is historical, the second socio-institutional. However, it should be remembered that both are not separate but pass into and determine each other.

Within this methodological frame, the main research problem of the article emerges. It can be expressed as follows: Do the attitudes of the Council's members allow predicting it as a crucial designer of incoming public debate on linguistic diversity and linguistic inclusion in Poland?

Aiming to address this issue, the authors reconstructed, in general, the views of the Council's members concerning the problem of linguistic diversity and linguistic inclusion, dating from the late 1990s until the present day. This set of opinions was evaluated according to the criteria of stability, coherency and intensity, enabling us to address the question: Is it appropriate to recognise the intellectual and axiological bonds between the Council's members as typical to the epistemic community in a sense proposed by Peter M. Haas (1992)? Being such a community means not only sharing aims and interests but also fundamental beliefs and values. Due to this, its existence seems to be an essential source of considerable agenda-setting potential for any institution engaged in a discussion on public matters.

The article consists of five sections. The introduction presents the methodological foundations of the analysis. Then, the historical context of the Polish experiences with language diversity and language inclusion has been sketched. After that, the legal foundations of the Council's activities and competences have been characterised. The fourth section creates the central part of the article, providing the description and evaluation of the most quoted and opinion-making publications delivered by the Council's members concerning linguistic diversity and linguistic inclusion in the Polish environment. In this part, the current statements of the Council's members regarding these issues were also approximated. The text concludes by referring to the historic-institutional embeddedness of the overall analysed materials. Moreover, a careful estimation is made about the Council's future position in Polish public discourses concerning linguistic diversity and linguistic inclusion.

\section{Historical Context}

Contemporary Polish culture remains immersed in a rich but discontinuous tradition of regulating and shaping linguistic situation.

An essential point of reference in this respect is the complex period of the Polish-Lithuanian Commonwealth's existence. Concerning the history of this state, many mythical imaginings have arisen and are continually cultivated. Undoubtedly, its past still resonates in the discussion on the relationship between Polish and other national identities rooted and developed in Central and Eastern Europe.

The Commonwealth covered a vast territory, settled by a profoundly diversified population in its ethnic, cultural, religious and language dimensions. Thus, for several centuries, the experience of language variety was a particularly important factor in reshaping cognitive horizons of the Polish-Lithuanian Commonwealth's inhabitants. Pluralism in the sphere of communication appeared to them as a natural phenomenon, which, however, does not mean that language issues did not generate vital controversies (Szul, 2009; Tazbir, 2011; Temčinas, 2017; Walczak, 2017, 2018).

After the final collapse of the Polish-Lithuanian Commonwealth in 1795, its former lands went under Austrian, Prussian and Russian rule. However, the borders of the partitions in the first half of the nineteenth century were fluent until 1846. Nevertheless, the divisions meant three separate language policies, which resulted in establishing three different cultures and sets of linguistic patterns. In Galicia, at the beginning of the 1860 s, autonomy was initiated and then developed, giving gradual rise to socio-political liberties also within the sphere of linguistic relations. However, in Prussia, and then in Germany, the policy of Germanisation was implemented (especially in times of Bismarck's chancellorship and further). Simultaneously, in Romanov's empire, the authorities were intensifying their pursuits to impose Russian in administration, courts, education and every- 
day life until 1905. Consequently, Polish and other local languages played a role of cultural ramparts for more than one hundred years (Burke, 2004; Cywiński, 2013; Pavlenko, 2009; Walczak, 1995).

The regaining of independence by Poland in 1918 again changed the linguistic situation significantly. In the restored state, Polish became a dominant language, receiving strong support from its authorities. Nevertheless, the society of the Second Polish Republic remained highly diverse, constituting a complicated ethnic, religious, cultural and linguistic mosaic. Minorities accounted for over $30 \%$ of the population, aspiring for various forms of autonomy, also including official status for their languages. The state agendas were calling for inter-cultural integration, but their endeavours proved not sufficient to weaken antagonisms successfully. Many internal and external factors did not allow the situation to change, including the following: massive poverty sharpening the ideological attitudes, the Great Depression, escalating popularity of nationalisms, postwar revisionisms, the destabilising influence of Germany and the USSR (Woźniak, 2015).

World War II brought about the occupation of Poland by the two states mentioned above. The linguistic situation in this period was transformed dramatically again. Under the Third Reich's control, German remained the only affirmed language. Slavic languages were seen as products of 'subhumans' (Untermenschen) who had to be turned into passive and obedient slaves of 'the master race' (Herrenvolk). The Bolsheviks theoretically claimed that the principle of linguistic equality, formulated by Lenin, remained in force. In practice, however, they aimed at spreading Russian to the maximum, in the USSR as well as the territories under its control. The policy resulted from the beliefs that broad dissemination of this language would facilitate administrative and governing processes, accelerating the desired social changes (Davies, 2010; Łuczak, 1979).

After World War II, Poland became a satellite state of the USSR. Importantly, it was created within completely new borders in comparison to those before 1939. The new territorial shape of Poland was imposed mostly by Stalin, while the Western allies approved his demands in Yalta and Potsdam. This was accompanied by a policy of mass resettlements, compulsory to a significant extent (Szul, 2009).

In the People's Republic of Poland, there were not many incentives and enhancements that would systematically encourage an individual to cultivate multilingualism. As part of the educational system, it was expected that the student should acquire proficiency in literary Polish and Russian-recognised as the language of international communication in the socialist bloc. The emphasis on learning other foreign languages was generally not strong. The few national minorities were struggling with numerous economic and administrative problems and experiencing the policy of their marginalisation or even stigmatisation (e.g., state-supported mass media campaigns disseminating negative ethnic stereotypes). As a result, learning minority language or cultivating it as a language of instruction remained limited. Such practices were reluctantly supported by the authorities, although regulated by bilateral international agreements (Pisarek, 1999).

\section{Socio-Institutional Context}

After 1989, Poland has experienced a kind of moderate return to the state of multilingualism. The doctrine of a society without national minorities is not applicable anymore. In 2005, Poland adopted the Act on National and Ethnic Minorities and on the Regional Language and in 2009 ratified the European Charter for Regional or Minority Languages. This created the legal basis for practising a broad spectrum of language rights by national minorities, especially in culture and education but under some conditions also in topographic and administrative spheres (e.g., schools with minority languages as languages of instruction, access to public broadcasting with TV and radio programs in minority languages, double names of topographic objects in the areas of Poland inhabited numerously by the national minorities representatives, the possibility to use the minority language in local public offices; see Kleina \& Lemańczyk, 2018; Łodziński, 2019).

Russian ceased to be a compulsory foreign language in every Polish school. This solution in the last decade of the 20th century led to its general displacement by other foreign languages, mainly English, as well as German, Spanish, French, Italian. Nowadays Russian is gradually regaining its popularity among young Poles, primarily focusing on a perspective of economic or cultural cooperation with partners from the post-Soviet countries. However, the question of its popularisation remains controversial to some extent (Pawłowski, 2008, pp. 130-131). The opening of borders and Poland's accession to the European Union have stimulated an increased demand in linguistic education. Teaching languages is no longer a matter of individual passion or ideological obligations but remains associated with specific challenges and opportunities that are currently met worldwide.

It is of great importance to notice that after the 2004 enlargement of the European Union until 2017, the number of Poles who temporarily stayed abroad increased from 1 million to over 2.5 million (Central Statistical Office, 2019; see also Table 1). This means the on-going internationalisation of Polish society, which, among others, results in growing numbers of bilinguals and multilinguals.

Simultaneously, over the last 30 years, Poland has developed its economy significantly. This growth makes it more and more attractive to foreigners. Particularly, in recent years, the movement of people to Poland from the post-Soviet countries has reached a mass scale. Migrations are of various types, but most often, foreigners come in search of work, education, security and 
Table 1. Estimation of emigration from Poland for a temporary stay in 2004-2005 and 2010-2018 (number of people staying abroad at the end of the year).

\begin{tabular}{llllllllllll}
\hline Year & 2004 & 2005 & 2010 & 2011 & 2012 & 2013 & 2014 & 2015 & 2016 & 2017 & 2018 \\
\hline Overall & 1000 & 1450 & 2000 & 2060 & 2130 & 2196 & 2320 & 2397 & 2515 & 2540 & 2455 \\
\hline
\end{tabular}

Source: Central Statistical Office (2019).

safety. Their activity should be recognised as an essential element of the Polish cultural characteristic, seriously influencing the language situation. Profound changes open questions not only of linguistic diversity but also of linguistic inclusion. In consequence, both issues become more and more often a subject of theoretical considerations, legal amendments and practical endeavours (Korniychuk, 2016).

According to these notions, the number of migrants staying temporarily in Poland in $\mathbf{2 0 1 0}$ was still less than 30,000 but in 2020 it reached over 270,000 (Office for Foreigners, 2020; see also Table 2).

Moreover, while in 2010 the Ministry of Labour, Family and Social Policy registered 180,000 declarations on entrusting work to a foreigner in Poland, in 2019 the number of these declarations exceeded 1,700,000 (Ministry of Family, Labour and Social Policy, 2017, 2020; see Table 3).

The vast majority of migrants in Poland are Ukrainians, and people from outside Europe are not numerous. However, especially in 2015-2016, in the course of the European migration crisis, the flows of individuals from the Middle East and North Africa became the subject of intense public debate. Particularly, politi- cians of Law and Justice strongly opposed Poland's opening to the influx of migrants from these regions. At the same time, other mainstream parties were generally suggesting a more flexible approach.

Within the context of dynamic changes, the institutional foundations of Polish language policy remain significantly stable. Its main principles were determined in the Constitution of the Republic of Poland 1997, which establishes Polish as the official language. However, the reservation has also been made that this provision "shall not infringe upon national minority rights resulting from ratified international agreements" (National Assembly of Poland, 1997).

At the same time, the Polish Language Act 1999, defines the general directions and aims of the Polish language policy, indicating instruments and mechanisms for its implementation (Parliament of Poland, 1999). The ideological overtone of the act is especially expressed in the preamble which recalls "the experience of history when the struggle of partitioners and occupiers with the Polish language was an instrument of denationalisation" (Parliament of Poland, 1999). Moreover, this part of the law characterises the Polish language as "a basic element of national identity" which helps to protect it "in the

Table 2. Estimation of emigration to Poland for a temporary stay in 2010-2020.

\begin{tabular}{lccccccccccc}
\hline Year & 2010 & 2011 & 2012 & 2013 & 2014 & 2015 & 2016 & 2017 & 2018 & 2019 & 2020 \\
\hline $\begin{array}{l}\text { Number of } \\
\text { migrants }\end{array}$ & 26488 & 29188 & 34210 & 34488 & 37668 & 60380 & 97821 & 140070 & 177033 & 230623 & 275802 \\
\hline
\end{tabular}

Source: Office for Foreigners (2020).

Table 3. Declarations on entrusting work to a foreigner in 2010-2020. (Only citizens of Armenia, Belarus, Georgia, Moldova, Russia and Ukraine may work on the basis of the declaration on entrusting work to a foreigner. This is a simplified procedure).

\begin{tabular}{|c|c|c|c|c|c|c|c|c|c|c|c|}
\hline Year & 2010 & $\begin{array}{c}2011 \\
\text { (1st half } \\
\text { of the } \\
\text { year) }\end{array}$ & 2012 & $\begin{array}{c}2013 \\
\text { (2nd half } \\
\text { of the } \\
\text { year) }\end{array}$ & 2014 & 2015 & 2016 & 2017 & 2018 & 2019 & $\begin{array}{l}2020 \\
\text { (1st half } \\
\text { of the } \\
\text { year) }\end{array}$ \\
\hline $\begin{array}{l}\text { Number of } \\
\text { declarations } \\
\text { registered } \\
\text { by Poviat } \\
\text { Labor } \\
\text { Offices }\end{array}$ & 180073 & 163984 & 243736 & 89363 & 387398 & 782222 & 1314127 & 1824464 & 1582225 & 1722977 & 670430 \\
\hline
\end{tabular}

Source: Ministry of Family, Labour and Social Policy, 2017, 2020. 
process of globalisation" (Parliament of Poland, 1999). Additionally, the legislator claimed that "Polish culture is a contribution to the building of a common, culturally diverse Europe" (Parliament of Poland, 1999) as well as proclaimed that all public agendas in Poland, as well as Polish citizens, are obliged to protect it.

The document ensures a special place for the Council, whose status and competences are regulated in chapter 3 (Parliament of Poland, 1999; Stroińska \& Andrews, 2018; Wiertlewski, 2011).

The body counts above 30 members, grouping currently mainly linguists (25), journalists (2), an IT specialist, a lawyer, social scientists (2), a theoretician of literature, a poet/writer, an actor, a cultural anthropologist, a military specialist and a theologist.

According to the Rules of Procedure of the Polish Language Council at the Presidium of the Polish Academy of Sciences (Polish Language Council, 2019), the Council used to operate under the Resolution by the Presidium of the Polish Academy of Sciences No. 17/96 1996 initially. Then, the Polish Language Act 1999 became the legal basis for incorporating the Council into the system of state institutions. In 1996-2000, the President of the Council was Walery Pisarek; then, in 2000-2019, Andrzej Markowski stepped in. Katarzyna Kłosińska has performed this function since 2019.

In light of the relevant provisions of The Polish Language Act 1999 (Parliament of Poland, 1999, section 12.1), the Council is an opinion-making and advisory body. It reflects on the Polish language condition and use, acting as a scientific committee within the meaning of article 34 of the Act on the Polish Academy of Sciences 2010 (Parliament of Poland, 2010). The Council term of office is four years.

At least every two years, the body presents a report on the protection of the Polish language to the Sejm and Senate (Parliament of Poland, 1999).

Also, the Council, at the request of numerous state institutions, as well as on its own initiative:

Expresses, by way of a resolution, opinions on the use of the Polish language in public activities, in a trade involving the participation of consumers as well as in the process of labour law implementation in the territory of Poland, and establishes the rules of spelling and punctuation of the Polish language. (Parliament of Poland, 1999)

Scientific societies, associations of artists and universities also may contact the Council in matters of using Polish. In case of 'significant concerns' regarding the official use of Polish, the opinion of the Council may be sought by numerous state- or self-government organs and agendas. Furthermore, a manufacturer, importer and distributor of a good or service, for which there is no appropriate name in Polish, may apply to the Council for an opinion on the appropriate language form for marking this good or service.
The Council does not include politicians, distinguishing it from many other state institutions. Therefore, the findings of the Council are not the result of political rivalry, but discussions among experts in matters of language and its practical applications.

The Council's scientific authority is confirmed by its close cooperation with many linguistic bodies. Jerzy Bralczyk and Andrzej Markowski indicated as particularly important the Committee of Linguistics (the Polish Academy of Sciences), the Institute of Polish Language (the Polish Academy of Sciences), the Commission for the Language Culture of the Warsaw Scientific Society, the Polish Linguistic Society, the Society of Polish Language Lovers, the Society for Language Culture, and other educational institutions and publishing houses.

According to Bralczyk and Markowski (2005), the Council should be the primary institution conducting Polish language policy. However, it "should make more use of the current linguistic research of the Institute of Polish Language at the Polish Academy of Sciences and university institutions" (Bralczyk \& Markowski, 2005, p. 82).

The Council's members often underline that their voices, as well as the whole body's voice, should serve primarily as a diagnostic source. They do not perceive themselves as the Polish language owners, executing the right to decide how its users should speak or write. The Council functions following the emancipatory model, directed to develop linguistic consciousness and invigorate discussion concerning the Polish language as a common good (Polish Language Council, 2020).

However, the Council's representatives also do not forget the past, frequently coping with traditions of managing linguistic diversity developed by the PolishLithuanian Commonwealth and Polish state between two world wars. These legacies are profoundly complicated, delivering cultural richness mixed with deep symbolic conflicts. Addressing them, the Council's members quite often suggest how to rethink and transform old patterns in new circumstances (Gajda, 2019).

\section{Discussion of the Data}

The discussion concerns works of the Council's members who are recognised in the Polish academic world as leading experts in conceptualising language policy issues.

The analysis is focused on publications regarding Polish language policy by Anna Dąbrowska (linguist, vice-president of the Council), Stanisław Gajda (sociolinguist, member of the Polish Academy of Sciences), Władysław T. Miodunka (linguist, chair of the Polish Language Abroad Section at the Council), Walery Pisarek (1931-2017, linguist, a specialist in the field of social communication and media studies, president of the Council in 1996-2000 and honorary president of the Council since 2000 until his death) and Władysław Lubaś (1932-2014, linguist, member of the Council in 2003-2006). 
The material was supported with the data of the survey "Dimensions and Conceptualisations of Polish Language Policy in Views of the Polish Language Council's Members," developed in July and August 2020 by Tadeusz Wallas, Tomasz R. Szymczyński and Bartosz Hordecki. The questionnaire of the research was addressed to all interested members of the Council. The survey referred to selected issues of Polish language policy, containing: questions of defining language policy, questions of status and the Polish language prospects, questions concerning European aspects of Polish language policy, and questions of linguistic transformations and challenges associated with intense migration flows to and from Poland.

The survey was answered by Andrzej Blikle (computer scientist), Anna Dąbrowska, Katarzyna Kłosińska (linguist, president of the Council), Władysław T. Miodunka and Barbara Sobczak (linguist). In response to the survey, Stanisław Gajda referred to his latest publication on language policy, also analysed in this article.

The statements derived from the data, exposed in the text, were translated by the authors of the article.

By analysing the collected material, an attempt was made to reconstruct the overall attitudes of the Council's members referring to the issues of language diversity and language inclusion in Poland. The nature of these attitudes was assessed in three main dimensions which were their stability, coherence and intensity. While assessing stability, a question was considered whether significant changes in the Polish migration situation were indicating essential shifts in the Council members' opinions. While considering the coherence, the problem was raised whether the attitudes analysed are mainly supportive or polemical to each other. While referring to the intensity, the authors of the article took into account two aspects: (1) How many of the Council's members did express a deep interest in the subject of linguistic diversity and linguistic inclusion? (2) Were these issues a frequent subject of the Council's attention?

In light of the materials chosen, Polish as the official language remains at the centre of the Council's attention and activity. Nevertheless, over the years, the body more and more often has been focusing its interest on other languages.

Walery Pisarek-the first president of the Council, and then its honorary president-convincingly pointed out this issue almost ten years ago. He expressed his comments in the text entitled The Language Policy of the Republic of Poland, a Member State of the European Union (Pisarek, 2012). The Council presents this material on its website, probably as a kind of signpost in thinking about language policy issues.

According to the author's words:

While in the 70s and 80s, language policy was equated with language pedagogy, with combating forms, especially borrowed ones, considered to be erroneous, derailed and inappropriate, starting from the 1980s, the benevolent attention of Polish linguists turned to the languages of national minorities in Poland and unveiling - in the name of the truth - the manipulative nature of slogans on posters and banners. (Pisarek, 2012, p. 332; emphasis in original)

Moreover, the author continued:

In the 1990s, as described by many authors, there was a characteristic shift in the subject of Polish language policy. Then, in the twenty-first century, the framework for the discussion on language policy [happening] in Poland was moved from a national one, close to the French model, to a civic one, closer to the British model. (Pisarek, 2012, p. 333; emphasis in original)

In recent years, Pisarek's diagnosis has been even more adequate. There came a time when the Council had undertaken some loud initiatives aimed at the evaluation and improvement of the linguistic layer of the Polish public debate. In this context, it is worth mentioning the Council's social campaign "You Speak-I Feel. The Good Word-A Better World" concerning ethics of speaking and prevention of verbal violence in various social spaces. Besides, the Council's report for the years 2016-2017, which was devoted to assessing the state of Polish in political communication, resonated strongly in public opinion. The study, prepared by Kłosińska, Zimny, and Żukiewicz (2018), carefully examined the news tickers accompanying Wiadomości, the leading news service broadcasted by the Polish public television. In particular, this document brought about a conclusion that in light of the expertise, the journalists "do not provide citizens with objective information, but their own vision of the events in question" (Kłosińska et al., 2018, p. 7). The Council therefore critically assessed the activities of the public broadcaster controlled by the Polish state. It is an eloquent example that the body is determined to position itself as an objective reviewer of speech practices enacted by all participants of the Polish public sphere (Kłosińska et al., 2018, p. 7; Zgółka, 2019).

In the context indicated by Pisarek, the Council has so far focused primarily on two issues related to the differentiation of the linguistic reality in Poland. The first concerns the status of the Polish language in the European Union, as well as activities aimed at popularising and promoting it at home and abroad. The second covers numerous and complicated issues of the Polish state's attitude towards minority and foreign languages. It also refers to the influence of language policy in this area on the linguistic situation and inter-ethnic relations in Poland.

Both issues were raised in a final resolution paper approved by the participants of the Conference entitled "Polish Communication and Language Policy in the Face of the Challenges of the 21st Century" (co-organised by the Council on October 21-23, 2004; see Pisarek, n.d.). Concerning the status of the Polish language in the 
European Union, the authors of the document were calling rather idealistically for planned and consistent efforts to strengthen the real presence of Polish in the everyday work of European Union bodies. Regarding the complicated issues of the Polish state's attitude towards minority and foreign languages, the resolution stated that "in order to meet the challenges resulting from the European integration...issues of multiculturalism should be introduced into the didactic and educational process, which will contribute to increasing respect for other cultures and tolerance towards ethnically and culturally distinct people" (Pisarek, n.d.; cf. Dąbrowska, Miodunka, \& Pawłowski, 2012; Lubaś, 2009; Pawłowski, 2005, 2008; Warchala, 2013).

In this context, Pisarek formulated an opinion that the Polish state's obligations towards migrants are not limited only to ensuring their right to practice native languages privately and in specific dimensions of public life. Moreover, according to his position, Poland should provide migrants with a wide range of educational services that would guarantee them successful learning of the official language. Moreover, the Polish state should also respond to their needs in teaching native languages. As the author stated:

Immigrants in Poland should learn Polish (similar to Polish emigrants in Austria, France, Germany, Sweden or the USA who learn German, French, Swedish and English) as its knowledge enables and conditions full participation in public life in multilingual Poland inhabited by multilingual citizens, where the official language is Polish. And they should be helped by the Polish state in learning Polish, which is a foreign language for them, as well as in teaching their mother tongue. (Pisarek, 2012, pp. 336-337; see also Zgółka, 2011)

Importantly, Pisarek emphasised that the implementation of the tasks proposed by him should not be considered only in the category of burdens for Poland and its budget. Polish authorities' openness to the needs of migrants should mean tangible benefits for Poles and the Polish language abroad. In connection with the principle of reciprocity, it can be expected that: "Such a solution...would enable the language of a few hundred thousand Polish diaspora in Germany to be granted with the status of a national minority language" (Pisarek, 2012, p. 337).

Pisarek's comments are very close to those of Władysław Lubaś, who claimed that the promotion of minority language rights in Poland was primarily motivated by the desire to join the European Union (Lubaś, 2012). At the same time, the author did not shy away from the assessment that "as a result of the nationalist resistance of some parties, sometimes we observe tardiness and mistrust towards non-Polish nationalities and their languages" (Lubaś, 2009, p. 466). Moreover, Lubaś (2009) pointed out that, like other post-communist states, Poland experiences a strong dispute as to the nature of the new state. In this context, according to this author, in the public debate "national views" prevail over "multi-ethnic views" and "civic views" (Lubaś, 2009, pp. 466-467).

Lubaś' diagnosis largely coincides with Stanisław Gajda's recommendations. Already in 1999, defining the aims of Polish language policy, he included among them: (1) promotion of languages other than Polish; (2) creation of conditions conducive to the preservation and development of national and ethnic minorities' languages; (3) training of language users with a rich linguistic personality, prepared for comprehensive participation in communication; (4) establishment of the Polish linguistic community, involving ethnic and national minorities and oriented on harmonious coexistence and development (Gajda, 1999, pp. 172, 182; Miodunka \& Tambor, 2018).

Moreover, a few years later, Gajda emphasised that Polish language policy should be viewed in the context of changes taking place throughout the European Union. According to the author, it should be expected that in the future within EU structures, there will be competition between three scenarios of ethnic and linguistic reality. These scenarios can be briefly described as multiculturalism, transculturalism and interculturalism. The first means "the relative separation of cultures from each other," and the second, "the integration of contacting cultures, the development of which aims to create a unified cultural melt" (Gajda, 2008, p. 61). Finally, interculturalism is, in a way, an intermediate variant, within the frame of which "interacting cultures $A$ and $B$ retain their distinctiveness and specificity, but at the same time a third C culture is created, common to the carriers of the cultures $A$ and B" (Gajda, 2008, p. 61).

It seems that nowadays sympathy towards the third scenario prevails among the members of the Council. This observation can be confirmed with some of their voices, obtained in July and August 2020.

Referring to the facilitating linguistic acclimatisation of migrants from the post-Soviet countries in Poland, Władysław T. Miodunka did not doubt that Poland should help them in learning Polish (e.g., free evening courses, access to textbooks in English, Ukrainian and Russian, launching the TVP channel for migrants from the East). He also drew attention to the fact that valuable activities are undertaken by local governments, although due to financial constraints on a limited scale. Katarzyna Kłosińska and Anna Dąbrowska also agreed that free Polish language courses for foreigners would be a good practice. They also recommended broad access to teaching aids for learning Polish, prepared in native languages of migrants and the possibility to watch $\mathrm{TV} /$ movies in cinemas with subtitles in these languages. Dąbrowska also suggested that linguistic inclusion programs for migrants working and living in Poland are insufficient. In her opinion, there is no long-term national plan in this respect. Barbara Sobczak, on the other hand, expressed her opinion in favour of actions "which could serve integration, and therefore should be focused 
on teaching migrants the Polish language and culture." Additionally, she opted for giving migrants easy access to Polish language courses, combined with good information about the possibilities in this area, preferably in their native languages. According to Sobczak, especially basic courses should be free, and the sphere of distance learning well developed. Going further, Andrzej Blikle asserted that state support in the discussed sphere should be intended for all migrants, not only those from post-Soviet countries.

Parallelly, criticism dominates among the answers to the question about the promotion of bilingualism and multilingualism by the Polish state (inside and outside its territory). Referring to the issue, Miodunka stated in the survey that "such a policy is not implemented, excepting knowledge of a compulsory foreign language at the matura exam. It is run by academic institutions, but with rather poor results." Dąbrowska also assessed the activity of the Polish state in the discussed area as "quite poor." In her opinion, "local governments in schools do the most in this regard." Blikle, on the other hand, spoke more mildly, pointing to "enormous progress over the last 30 years" in the field of foreign languages teaching in Poland. At the same time, however, he emphasised that this assessment is relative, as it takes into account "previous negligence." In his opinion, it should not be forgotten that also in the case of multilingual people, knowledge of Polish as a mother tongue remains an essential competence.

All members of the Council who answered the survey in July-August 2020 believed that mass migration from post-Soviet states to Poland did not pose a threat to the Polish language. In justifying this assessment, Dąbrowska concluded that its accuracy was proved by various examples from other countries (Germany, Great Britain, Spain or Scandinavia). Following their experiences, she claimed in the survey, Poland should "promote and facilitate Polish learning as the language of the country of residence." At the same time, Miodunka expressed the view that migration processes "do not pose any threat to the Polish language, but on the contrary-prove its power and attractiveness, highlighting the fact that Polish is becoming an international language in Central Europe." Moreover, in light of Miodunka's position, the Polish state accurately supports this process by introducing special obligations to persons applying for the right of permanent residence in Poland (knowledge of Polish as a foreign language at the B1 level, confirmed with a certificate issued by the State Commission for the Certification of Proficiency in Polish as a Foreign Language).

In light of all of the sources discussed above, the Council members' views regarding linguistic diversity and linguistic inclusion in Poland can be characterised as significantly similar. It allows claiming that the Council's community shares an elaborated but not formalised vision of Polish language policy, especially involving a conviction that this policy should be focused on: (1) the Polish language promotion and (2) other languages cultivation. These two aims are perceived as supplementary and possible to achieve without conflicts and tensions between linguistic communities inhabiting Poland.

The mass influx of people unfamiliar with the Polish language was perceived by the Council's members as a challenge, but not a threat. They emphasised that the Polish state has significant linguistic obligations towards migrants. It is, in particular, about providing high-quality language courses that may enable them to acquire Polish as an official language. The Council's members also supported the opinion that learning Polish should go hand in hand with openness to preservation and development of migrants' native languages. The expenses in this area were presented as a kind of investment, aimed at strengthening the Polish authorities' position in striving to guarantee the Polish diaspora's language rights.

It is also essential to emphasise the strong continuity in the development of the views on linguistic diversity and linguistic inclusion in Poland, formulated by the Council's members for over the last 20 years. The overall tone of all analysed sources, as well as leading opinions expressed by their authors, has not changed (notwithstanding the profound social transformations).

As for the intensity: The Council's engagement in the discussion on linguistic diversity and linguistic inclusion in Poland should be estimated as moderate. A query of sources indicates that this issue regularly came up during the various events initiated by the Council and remained an important issue for some of its members. However, it cannot be said that this domain of problems was located in the centre of the whole body's interest.

The sources analysed are rooted primarily in linguistic knowledge, which results undoubtedly from the strong predominance of linguists among the Council's members. As a result, the opinions taken into consideration appear to be synthetic rather than analytical, general rather than detailed. Simultaneously, it is evident that the views of the body representatives are based on broad knowledge about the Polish linguistic past, being presented as a meaningful inspiration but also a cautionary tale for the present and future. However, the sources did not usually contain references to sociological theories, which can serve as a basis for interpretation and predictions concerning the development of the linguistic situation in Poland. There were also no references to extensive empirical diagnoses concerning the social dimension of bilingualism and multilingualism in the Polish environment. The issue of tensions and conflicts rooted in the linguistic background was not discussed in detail but accompanied by postulates of harmonious linguistic coexistence in contemporary Poland. However, these postulates require in-depth comprehension of their possibility conditions. It seems to be one of the most urgent challenges for the Council's representatives.

\section{Conclusion}

The high level of stability and coherence of the statements analysed in the text allows saying that their 
authors contribute to the epistemic community as understood by P. M. Haas. It has at least a national scope, including academics from various disciplines, but with a vast majority of linguists. Its members have developed and proliferated:

(1) A shared set of normative and principled beliefs, which provide a value-based rationale for the social action of community members; (2) shared causal beliefs, which are derived from their analysis of practices leading or contributing to a central set of problems in their domain and which then serve as the basis for elucidating the multiple linkages between possible policy actions and desired outcomes; (3) shared notions of validity-that is, intersubjective, internally defined criteria for weighing and validating knowledge in the domain of their expertise; and (4) a common policy enterprise-that is, a set of common practices associated with a set of problems to which their professional competence is directed, presumably out of the conviction that human welfare will be enhanced as a consequence. (Haas, 1992, p. 3)

The activity and statements of the Council's members appear to be based on the belief that the Polish state should cultivate values of open patriotism in the field of language policy (generally understood as promotion of Polish as the official language plus respect for minority language rights following the European Charter). According to their claims, such patriotism finds its strength in diversity and pluralism, interpreting intercultural meetings as an inspiration and an opportunity to share ideas and design new cultural patterns.

In light of many statements endorsed by the Council's members, the implementation of the appropriate solutions requires a reasonable reconstruction of Polish selfperception. According to Gajda (2019, p. 25):

The new project of Polishness should combine Polish identity with universal values, so while maintaining national uniqueness, it should create a new quality, patriotism more open to the affairs of the world and politically responsible. This project also includes a patriotic language policy that creates linguistic consciousness and influences linguistic behaviour oriented not only towards linguistic correctness and immediate effectiveness but also ethical responsibility.

Members of the Council also did not abstain from emphasising that contemporary Polish identity requires being modernised and reshaped by breaking old discursive patterns and divisions. According to Kłosińska, it would be particularly desirable to develop models that can narrow the gap between vocabularies of 'uncompromising ethics' (based on the assumption that politics is a moral battle for fundamental values and symbols) and 'technocratic pragmatism' (based on the assumption that politics is a utilitarian game of interest and influences), which has evolved parallelly after 1989. Thanks to this, Kłosińska claimed, Poles would have a chance to "redefine the concepts that are fundamental to both discourses" and determine new priorities of their national community (Kłosińska, 2012, p. 313). It is hoped that this achievement may ease the inclusion of migrants into the circuit of contemporary Polish socio-cultural life, diversifying it constructively and adjusting to the challenges of the 21 st century.

Moderation present in various statements delivered by the Council's members can also be understood as an expression of responsibility, implied by belonging to the body co-shaping Polish linguistic awareness. It should be noted that the intensive migration flows so far have not resulted in the chronic politicisation of linguistic issues in Poland. Admittedly, linguistic change was temporarily the subject of intense political debate in the second half of the 1990s, when the Polish language law was adopted. At that time, the plot of the not very precisely defined threat to the Polish language was exploited. In consequence, there were concerns that the Polish Language Act 1999 would become one of the instruments of instilling conservative-national or even xenophobic postulates in the policy of the Polish state (the preamble of the document was a good basis for such expectations). However, shortly after the adoption of the law, the enthusiasm of politicians towards debating language policy issues declined (excluding vivid deliberation on the status of the Silesian). On the other hand, the Council, strengthened by this regulation, for more than two decades of its activity, have confirmed itself as an institution that consistently promotes and animates world-view pluralism as well as civic virtues within the Polish communication sphere.

Currently, the language issue is not the subject of significant collective controversies in Poland. Especially, political actors do not undertake it to distinguish themselves from their rivals. Nevertheless, the changing demographic situation allows assuming that language policy dilemmas soon may attract the attention of public opinion again. Moreover, in the context of increasing linguistic diversification, the attitudes in this sphere can transform into new notable socio-political divisions. Moreover, the intensifying populist discourse in Poland also seems to create a climate in which matters of language policy can be used as an instrument for mobilising and antagonising social groups.

For the above reasons, it may be advisable if the Council in the coming years intensify its reflection referring to the issues of linguistic diversity and linguistic inclusion. It can be admitted that the body have built and focused around itself a community of people who have a potential to present coherent, in-depth and wellbalanced conceptualisations of Polish language policy. These achievements would be essentially helpful in constituting future directions in the process of elevating linguistic awareness and openness among Polish society. 


\section{Acknowledgments}

We would like to thank Tomasz R. Szymczyński, who is the co-author of the survey "Dimensions and conceptualisations of Polish language policy in views of the Polish Language Council's members." We would like to extend our sincere thanks to Katarzyna Kłosińska and Barbara Sobczak who helped us disseminate the survey among the members of the Polish Language Council. We deeply appreciate the responses received from Andrzej Blikle, Anna Dąbrowska, Stanisław Gajda, Katarzyna Kłosińska, Władysław T. Miodunka and Barbara Sobczak.

\section{Conflict of Interests}

The authors declare no conflict of interests.

\section{References}

Bralczyk, J., \& Markowski, A. (2005). Rola i miejsce instytucji językoznawczych w kształtowaniu polityki językowej [The role and place of linguistic institutions in shaping language policy]. In A. Markowski \& J. Porayski-Pomsta (Eds.), Polska polityka komunikacyjnojęzykowa wobec wyzwań XXI wieku [Polish communication and language policy in the face of the challenges of the 21st century] (pp. 82-89). Warsaw: Elipsa.

Burke, P. (2004). Languages and communities in early modern Europe (1st ed.). Cambridge: Cambridge University Press.

Central Statistical Office. (2019). Informacja o rozmiarach i kierunkach czasowej emigracji z Polski w latach 2004-2018 [Information on the size and directions of temporary emigration from Poland in the years 2004-2018]. Warsaw: Główny Urząd Statystyczny. Retrieved from https://stat.gov.pl/download/ gfx/portalinformacyjny/pl/defaultaktualnosci/5471/ 2/12/1/informacja_o_rozmiarach_i_kierunkach_ czasowej_emigracji_z_polski_w_latach_20042018.pdf

Cywiński, B. (2013). Szańce kultur. Szkice z dziejów narodów Europy Wschodniej [Ramparts of cultures. Sketches from the history of the Eastern Europe's nations] (1st ed.). Warsaw: Centrum Europejskie Natolin-Wydawnictwo Trio.

Dąbrowska, A., Miodunka, W., \& Pawłowski, A. (2012). Wyzwania polskiej polityki językowej za granicą: Kontekst, cele, środki i grupy odbiorcze [Challenges of the Polish language policy abroad: Context, objectives, means and target groups] (1st ed.). Warsaw: Ministerstwo Spraw Zagranicznych.

Davies, N. (2010). Boże igrzysko. Historia Polski [God's playground: A history of Poland] (7th ed.). Kraków: Znak.

Ministry of Family, Labour and Social Policy. (2017). Foreigners working in Poland-Statistics. Ministry of Family, Labour and Social Policy. Retrieved from https://archiwum.mpips.gov.pl/analizy-i-raporty/ cudzoziemcy-pracujacy-w-polsce-statystyki

Ministry of Family, Labour and Social Policy. (2020). Declarations on entrusting work to a foreigner in 2018-2020. Ministry of Family, Labour and Social Policy. Retrieved from https://psz.praca.gov.pl/-/ 8180211-oswiadczenia-o-powierzeniuwykonywania-pracy-cudzoziemcowi-wpisane-doewidencji-oswiadczen-obowiazujace-od-2018-r-

Fishman, J. A. (1997). The sociology of language. In N. Coupland \& A. Jaworski (Eds.), Sociolinguistics: $A$ reader (1st ed.). London: Palgrave.

Gajda, S. (1999). Program polskiej polityki językowej [Polish language policy programme]. In J. Mazur (Ed.), Polska polityka językowa na przełomie tysiqucleci [Polish language policy at the turn of the Millennium] (pp. 37-46). Lublin: Wydawnictwo UMCS.

Gajda, S. (2008). Językowa przyszłość a polityka językowa [Language future and language policy]. In J. Warchala \& D. Krzyżyk (Eds.), Polska polityka językowa w Unii Europejskiej [Polish language policy in the European Union] (pp. 50-66). Katowice: Wydawnictwo UŚ.

Gajda, S. (2019). Polska polityka językowa 1918-2018 [Polish language policy 1918-2018]. In R. Przybylska, B. Batko-Tokarz, \& S. Przęczek-Kisielak (Eds.), Niepodległa wobec języka polskiego [Independent Poland and the Polish language] (pp. 13-27). Kraków: Wydawnictwo UJ.

Haas, P. M. (1992). Introduction: Epistemic communities and international policy coordination. International Organization, 1(46), 1-35.

Kleina, K., \& Lemańczyk, M. (Eds.). (2018). Różnorodność językowa w Polsce jako dobro wspólne (wybrane przykłady) [Linguistic diversity in Poland as a common good (selected examples)] (1st ed.). Warsaw: Kancelaria Senatu.

Kłosińska, K. (2012). Na ile sposobów mówimy o sprawach publicznych? [How many ways do we talk about public affairs?]. In A. Markowski \& R. Pawelec (Eds.), Oblicza polszczyzny [Faces of the Polish language] (pp. 305-313). Warsaw: Narodowe Centrum Kultury.

Kłosińska, K., Zimny, R., \& Żukiewicz, P. (2018). Sprawozdanie ze stanu ochrony języka polskiego za lata 2016-2017-Język informacji politycznej [Report on the Polish language protection 2016-2017Language of political information]. Polish Language Council. Retrieved from https://rjp.pan.pl/ images/Sprawozdanie_o_stanie_ochrony_j\%C4\% 99z._pol._2016-2017.pdf

Korniychuk, A. (2016). Nauka języka w integracji uchodźców-Doświadczenia innych państw [Language learning in refugee integration-Experiences of other countries] (1st ed.). Warsaw: Instytut Spraw Publicznych. Retrieved from https://www. isp.org.pl/pl/publikacje/nauka-jezyka-w-integracjiuchodzcow-doswiadczenia-innych-panstw

Łodziński, S. (2019). Języki mniejszości narodowych 
w przestrzeni publicznej. Czy zmiana krajobrazu językowego w Polsce? [Languages of national minorities in public space. Is the language landscape in Poland changing?]. Nauka, 3, 125-145.

Lubaś, W. (2009). Polityka językowa. Komparacja współczesnych języków słowiańskich [Language policy. Comparison of contemporary Slavic languages] (1st ed.). Opole: Wydawnictwo UO.

Lubaś, W. (2012). O polskiej polityce językowej [On Polish language policy]. Poradnik Językowy, 6, 11-33.

Łuczak, C. (1979). Polityka ludnościowa i ekonomiczna hitlerowskich Niemiec w okupowanej Polsce [The demographic and economic policy of Nazi Germany in occupied Poland] (1st ed.). Poznań: Wydawnictwo Poznańskie.

Miodunka, W., \& Tambor, J. (Eds.). (2018). Nauczanie i promocja języka polskiego $w$ świecie: Diagnozastan-perspektywy [Teaching and promotion of the Polish language in the world: Diagnosis-conditionprospects] (1st ed.). Katowice: Wydawnictwo Uniwersytetu Śląskiego.

Office for Foreigners. (2020). Estimation of emigration to Poland for a temporary stay in 2010-2020. Office for Foreigners. Retrieved from https://migracje.gov.pl/statystyki/zakres/polska/ typ/dokumenty/widok/tabele/rok/2020

National Assembly of Poland. (1997). The Constitution of the Republic of Poland. Warsaw: Parliament of Poland.

Parliament of Poland. (1999). Polish Language Act 1999. Warsaw: Parliament of Poland.

Parliament of Poland. (2010). The Act on the Polish Academy of Sciences 2010. Warsaw: Parliament of Poland.

Pavlenko, A. (2009). Linguistic russification in the Russian Empire: Peasants into Russians? Russian Linguistics, 1(33), 331-350.

Pawłowski, A. (2005). Język polski w Unii Europejskiej: Szanse i zagrożenia [The Polish language in the European Union: Opportunities and threats]. Poradnik Językowy, 10, 4-27.

Pawłowski, A. (2008). Zadania polskiej polityki językowej w Unii Europejskiej [Polish language policy's tasks in the European Union]. In J. Warchala \& D. Krzyżyk (Eds.), Polska polityka językowa w Unii Europejskiej [Polish language policy in the European Union] (pp. 113-147). Katowice: Wydawnictwo UŚ.

Pisarek, W. (1999). Istota i sens polskiej polityki językowej [The essence and meaning of Polish language policy]. In J. Mazur (Ed.), Polska polityka językowa na przełomie tysiqcleci [Polish language policy at the turn of the Millennium] (pp. 13-23). Lublin: Wydawnictwo UMCS.

Pisarek, W. (2012). Polityka językowa Rzeczypospolitej Polskiej, państwa członkowskiego Unii Europejskiej [Language policy of the Republic of Poland, a member state of the European Union]. In A. Markowski \& R. Pawelec (Eds.), Oblicza polszczyzny [Faces of the
Polish language] (pp. 331-341). Warsaw: Narodowe Centrum Kultury.

Pisarek, W. (n.d.). Uchwała końcowa konferencji Polska polityka komunikacyjnojęzykowa wobec wyzwań XXI wieku [Final resolution of the conference Polish communication and language policy in the face of the challenges of the 21st century]. Polish Language Council. Retrieved from https://rjp.pan.pl/index. php?option=com_content $\&$ view=article\&id=383: polska-polityka-komunikacyjnojzykowa-wobecwyzwa- $x$ xi- wieku\&catid $=50 \&$ Itemid $=50$

Polish Language Council. (2019). Regulamin Rady Języka Polskiego przy Prezydium Polskiej Akademii Nauk 2019 [Rules of procedure of the Polish Language Council at the Presidium of the Polish Academy of Sciences 2019]. Polish Language Council. Retrieved from https://rjp.pan.pl/index.php?option=com_ content \&view=article\&id=194:regulamin-rady\& catid $=40 \&$ Itemid $=48$

Polish Language Council. (2020). Oświadczenie Prezydium Rady Języka Polskiego w sprawie opinii językowej o słowie "Murzyn" [Statement of the Presidium of the Polish Language Council on the linguistic opinion about the word 'Murzyn']. Polish Language Council. Retrieved from https://rjp.pan.pl/index.php? option=com_content\&view=article\&id=1898\&catid= 98\&Itemid $=\overline{5} 9$

Schiffman, H. (2006). Language policy and linguistic culture. In T. Ricento (Ed.), An introduction to language policy. Theory and method (pp. 111-125). Oxford: Blackwell Publishing.

Stroińska, M., \& Andrews, E. (2018). The Polish Language Act: Legislating a complicated linguistic-political landscape. In E. Andrews (Ed.), Language planning in the post-communist era: The struggles for language control in the new order in Eastern Europe, Eurasia and China (pp. 241-260). Cham: Palgrave MacMillan.

Szul, R. (2009). Język-naród-państwo. Język jako zjawisko polityczne [Language-nation-state. Language as a political phenomenon] (1st ed.). Warsaw: PWN.

Tazbir, J. (2011). Język polski a świadomość narodowa [Polish language and national consciousness]. Polish Language Council. Retrieved from http://www. rjp.pan.pl/index.php?option=com_content\&view= article\&id $=1351 \&$ Itemid $=50$

Temčinas, S. (2017). Języki kultury ruskiej w Pierwszej Przeczypospolitej [Languages of the culture Russe in the Polish-Lithuanian Commonwealth]. In $\mathrm{M}$. Kuczyńska (Ed.), Między Wschodem a Zachodem: Prawosławie i unia [Between East and West: Orthodoxy and the Union] (pp. 81-120). Warsaw: Wydawnictwa Uniwersytetu Warszawskiego.

Walczak, B. (1995). Zarys dziejów języka polskiego [Outline of the history of the Polish language] (1st ed.). Wrocław: SAWW.

Walczak, B. (2017). Wielojęzyczność naszego świata dawniej i dziś [Multilingualism of our world: Past and 
present]. In M. Pachowicz \& K. Choińskia (Eds.), Świat słów. Jedność $w$ różności [The world of words. Unity in diversity] (pp. 17-26). Tarnów: Wydawnictwa PWSZ.

Walczak, B. (2018). Ruszczyzna-Drugi język Rzeczypospolitej [The Russian language as a second language of the Polish-Lithuanian commonwealth]. In L. Citko (Ed.), Języki ruskie w rozwoju historycznym i kontaktach z polszczyznq [Russian languages in historical development and contacts with Polish] (pp. 277-287). Białystok: Prymat.

Warchala, J. (2013). O współczesnej polszczyźnie w duchu polityki językowej i promocji [About contemporary Polish in the spirit of language policy and promotion]. In A. Achtelik \& J. Tambor (Eds.), Sztuka, więc rzemiosło. Nauczyć Polski i polskiego [Art, so craft. To make Poland and Polish learned] (Vol. 3, pp. 78-89). Katowice: Gnome.

Wiertlewski, S. (2011). Wielopodmiotowość współczes- nej polskiej polityki językowej [Multi-agency of contemporary Polish language policy]. Język, Komunikacja, Informacja, 6, 99-107.

Woźniak, E. (2015). Polityka językowa państwa polskiego w okresie międzywojennym [Language policy of the Polish state in the interwar period]. Socjolingwistyka, 29, 7-20.

Zgółka, T. (2011). Dydaktyka szkolna języka polskiego jako ojczystego w perspektywie europejskiej [School teaching of the Polish language as a mother tongue in the European perspective]. Polish Language Council. Retrieved from http://www.rjp.pan. $\mathrm{pl} /$ index.php?option=com_content $\&$ view=article\& id $=1356$ \& $\mid$ temid $=50$

Zgółka, T. (2019). Czas (dez)informacji [(Dis)information time]. Kultura u Podstaw. Retrieved from https:// kulturaupodstaw.pl/czas-dezinformacji-tadeuszzgolka-anka-adamowicz

\section{About the Authors}

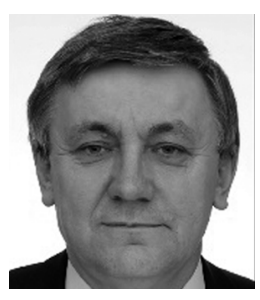

Tadeusz Wallas is a Professor habilitated in Political Science and Head of the Department of Political Culture at the Faculty of Political Science and Journalism at Adam Mickiewicz University in Poznań. He is scientifically interested in contemporary political systems, contemporary political culture, political aspects of globalisation and European integration.

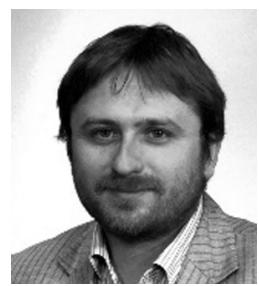

Bartosz Hordecki is an Assistant Professor at the Faculty of Political Science and Journalism at Adam Mickiewicz University in Poznań. He is a member of the Executive Board of the Research Committee 50: Politics of Language (International Political Science Association). He specialises in studies on language politics and policies, political philosophy and political rhetoric. His research also concerns the evolution of political and legal cultures as well as transformations of key-concepts and methodological approaches in political and media studies. 